\title{
PARASITES OF A SAITHE, POLLACHIUS VIRENS (L.) CAPTURED IN THE BALTIC SEA
}

\author{
Leszek ROLBIECKI ${ }^{1^{*}}$, Jerzy ROKICKI ${ }^{1}$, and Krzysztof SKÓRA ${ }^{2}$ \\ ${ }^{1}$ Division of Invertebrate Zoology, University of Gdańsk, Gdynia, Poland \\ ${ }^{2}$ Hel Marine Station, University of Gdańsk, Hel, Poland
}

Rolbiecki L., Rokicki J., Skóra K. 2008. Parasites of a saithe, Pollachius virens (L.) captured in the Baltic Sea. Acta Ichthyol. Piscat. 38 (2): 143-147.

Background. A female saithe, Pollachius virens (L.), caught in the Baltic Sea, off Polish coast, was infected with microsporidian Glugea sp., nematodes Anisakis simplex (L3), Contracaecum osculatum (L3), Hysterothylacium aduncum aduncum, $H$. aduncum gadi, and acanthocephalan Echinorhynchus gadi; each of which constitutes a new geographic locality record for these species in the Baltic Sea. H. aduncum aduncum and H. aduncum gadi are described, illustrated, and their detailed measurements are provided.

Keywords: parasites, fish, saithe, Pollachius virens, Baltic Sea, Poland, new host records

The saithe, Pollachius virens (L.) is a marine fish, representing the family Gadidae. It naturally occurs in the North Atlantic Ocean and it has been rarely reported from the Baltic Sea (Froese and Pauly 2008). The hitherto conducted parasitic surveys of this fish focused on the Atlantic, particularly the Sea of Norway and the Barents Sea (e.g., Rokicki and Strömberg 1991, Karasev et al. 1996, Strømnes and Andersen 1998, Lom 2002).

The Baltic Sea is a brackish inland body of water with salinities ranging from 3.7 PSU (Bothnian Bay) to 8 PSU (Pomeranian Bay) (Łomniewski et al. 1975). Its animaland plant species diversity is much lower than that of fullsalinity seas. It is particularly evident in the composition of its fish fauna and invertebrate fauna. The low species diversity of potential definitive, intermediate, or paratenic hosts may also theoretically affect the species richness of fish parasites (Rhode 2002, Zander and Reimer 2002). Therefore it would be interesting to compare the parasite faunas of saithe from the Baltic Sea and Atlantic Ocean. The results of the presently reported study comprise the first published parasite records of saithe from the Baltic Sea off Polish coast.

In March 2007, a single, semi-ripe female saithe, Pollachius virens ( $99 \mathrm{~cm} \mathrm{TL}, 9.2 \mathrm{~kg}$ ), was caught in the Gulf of Gdańsk. The fish was promptly subjected to a standard parasitological necropsy. The microsporidians found were smeared on a microscopic slide and mounted in glycerolgelatine. The nematodes and acanthocephalans were fixed in a mixture of acetic acid and formalin. Selected nematodes were cleared in lactophenol and mounted in glycerolgelatine. The acanthocephalans were stained in Gowers carmine, dehydrated in glacial acetic acid, and cleared in benzyl alcohol.

The following parasites were recovered from the fish examined

\section{MICROSPORA}

Glugea sp.: 3 spherical cysts, infecting intestine, $0.8 \mathrm{~mm}$ in diameter; spore $5.7-5.9 \mu \mathrm{m}(5.7 \mu \mathrm{m}) \times 1.5-2.1 \mu \mathrm{m}$ $(1.8 \mu \mathrm{m})$.

NEMATODA

Anisakis simplex (Rudolphi, 1809) L3: 474 specimens, including 1 nematode on the spleen, 17 on the intestine, 32 on the stomach (including 3 penetrating the stomach wall), 65 on the pyloric caecae, and 359 on the liver (134 on the one lobe and 225 on the other).

Contracaecum osculatum (Rudolphi, 1802): L3: 1 specimen on the liver.

Hysterothylacium aduncum aduncum (Rudolphi, 1802): 1 adult female (with eggs visible in her uterus) in the intestine (Fig. 1, Table 1)

Hysterothylacium aduncum gadi (Müller, 1776): 3 specimens in the intestine ( 2 females, including a mature one; 1 male) (Fig. 2, Table 1).

\section{ACANTHOCEPHALA}

Echinorhynchus gadi Müller, 1776: 3 specimens in the intestine ( 2 females, 1 male).

The presently reported study constitutes the first report on saithe parasites from the Baltic Sea. However, the helmints found have already been recorded from this fos outside the Baltic Sea. In addition, the genus Glugea was represented by Glugea punctifera Thélohan, 1895, infecting the connective tissue of the

\footnotetext{
* Correspondence: Dr Leszek Rolbiecki, Katedra Zoologii Bezkręgowców, Uniwersytet Gdański, Al. Piłsudskiego 46, 81-378 Gdynia, Poland, phone: +48 58 523 6638, fax: +48 58523 6630, e-mail: lrolbiecki@ocean.ug.gda.pl
} 


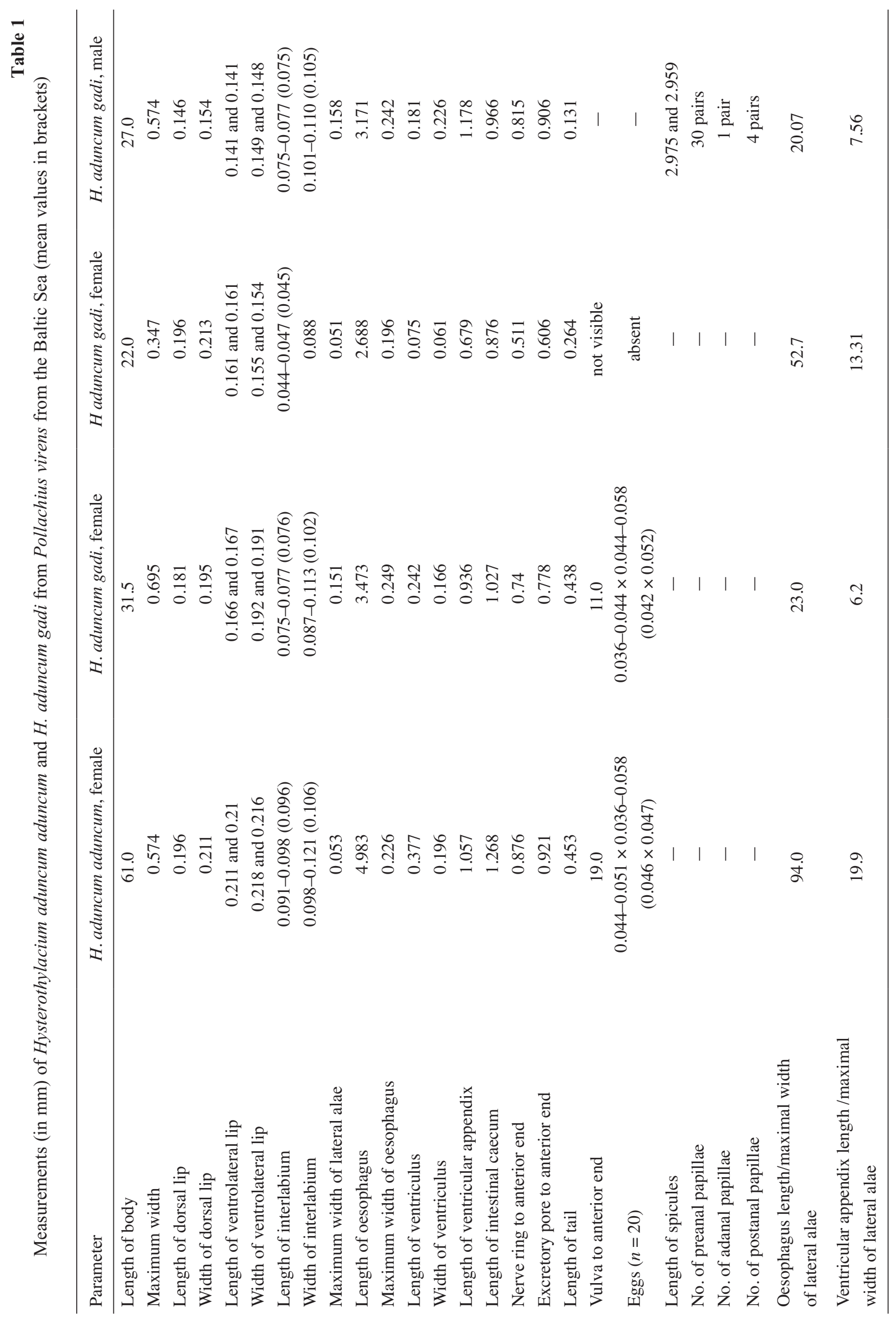


A

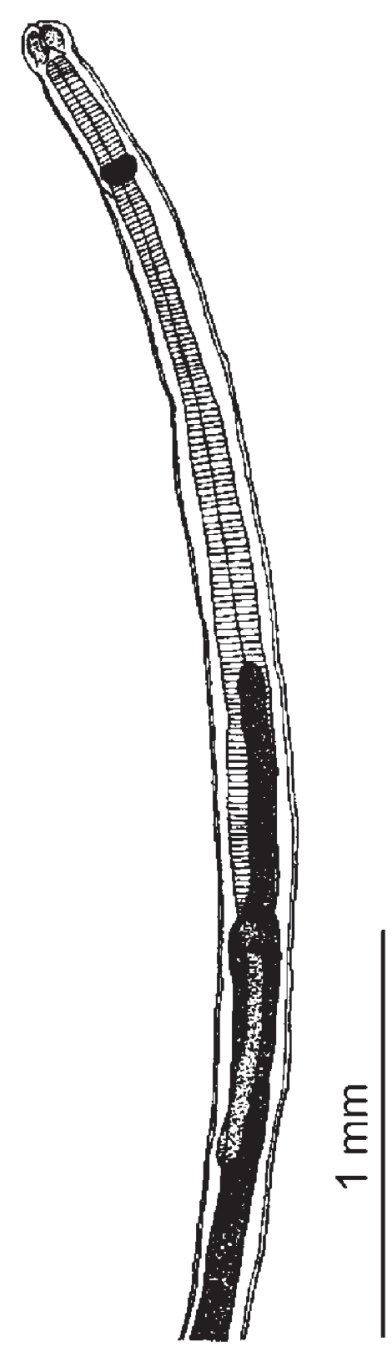

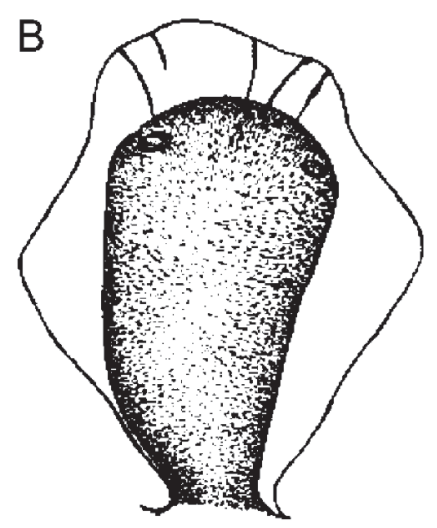

C
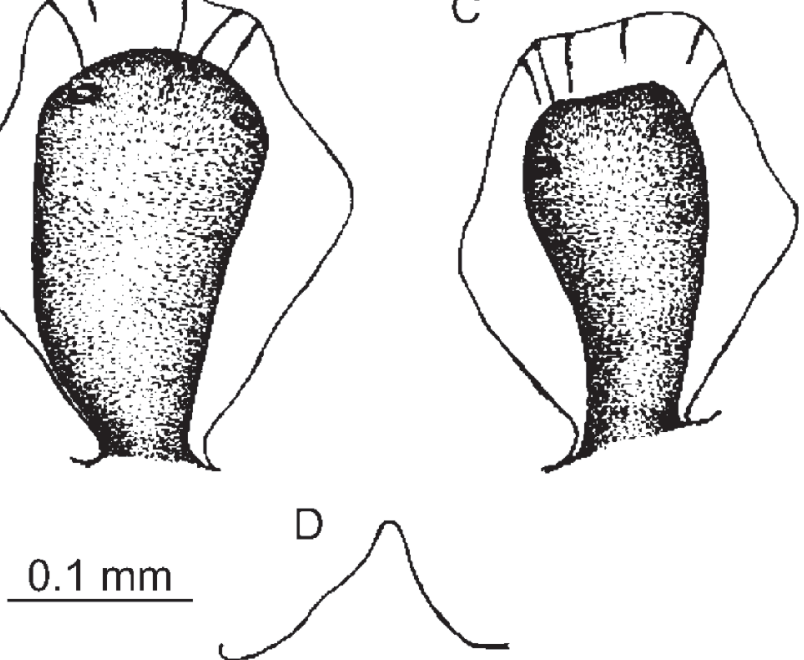

E

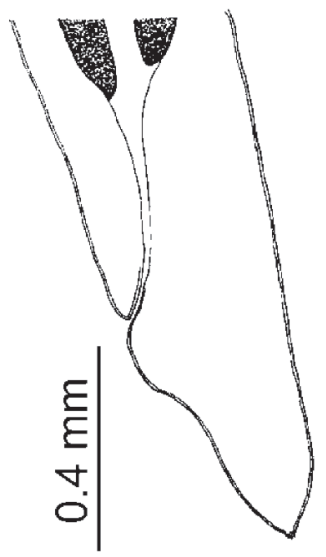

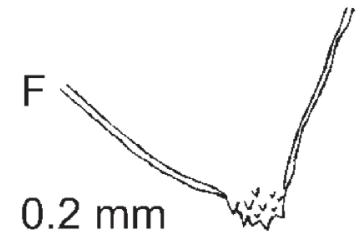

$\mathrm{G}$

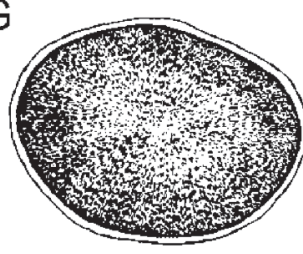

$0.05 \mathrm{~mm}$

Fig. 1. Hysterothylacium aduncum aduncum, female, from Pollachius virens from the Baltic Sea; $\mathrm{A}=$ head end, $\mathrm{B}=$ dorsal lip, $\mathrm{C}=$ ventrolateral lip, $\mathrm{D}=$ interlabium, $\mathrm{E}=$ posterior end, $\mathrm{F}=$ caudal process, $\mathrm{G}=\operatorname{egg}$

eye (Lom 2002). Other records of this genus in Polish fishes include:

Glugea anomala (Moniez, 1887) infecting three-spined stickleback, Gasterosteus aculeatus L., nine-spined stickleback, Pungitius pungitius (L.) (cf. MorozińskaGogol 2006), and flounder, Platichthys flesus (L.) (cf. Chibani and Rokicki 2004). Because the latter finding has not been confirmed by morphological examination it most probably represented Glugea stephani Hagenmüller, 1899, a parasite specific to flounder. Also the other species: Glugea acerinae Jirovec, 1930 was recorded in ruffe, Gymnocephalus cernuus (L.) (cf. Rolbiecki 2003).

The nematodes Anisakis simplex, Hysterothylacium aduncum (Rudolphi, 1802), and Contracaecum osculatum, as well as the acanthocephalan, Echinorhynchus gadi have frequently been encountered in fishes of the southern Baltic Sea (e.g., Rokicki 1975, 1995, Rokicki et al. 1993, Køie 1999, Rolbiecki and Rokicki 2000).

Hysterothylacium aduncum is among the most commonly reported species of its genus in Baltic Sea fishes.
Hartwich (1975) listed the sympatric congeners$H$. aduncum - infecting chiefly clupeids, H. auctum (Rudolphi, 1802) - infecting viviparous blenny, Zoarces viviparus (L.), and flatfishes, and $H$. gadi (Müller, 1776) _ infecting gadids in the Baltic Sea. Punt (1941) stated that $H$. aduncum and $H$. auctum were conspecific, based on morphological features of the lobes, while Petter and Cabaret (1995) delineated the subspecies H. aduncum aduncum and $H$. aduncum gadi based on cluster analysis of morphological parameters (i.e., ventricular caecum length, intestinal caecum length, oesophagus length, body length, and length of spicules /width of cervical alae). We ascribe to the sub-species classification established by Petter and Cabaret (1995). Balbuena et al. (1998) also agreed and noted the likely presence of a species complex associated with $H$. aduncum. We based our identification of Hysterothylacium aduncum gadi on the presence of prominent, wing-like alae - contributing to a characteristic bending in the anterior part of parasites (both males and females) (Fig. 2). Those alae are not observed in 

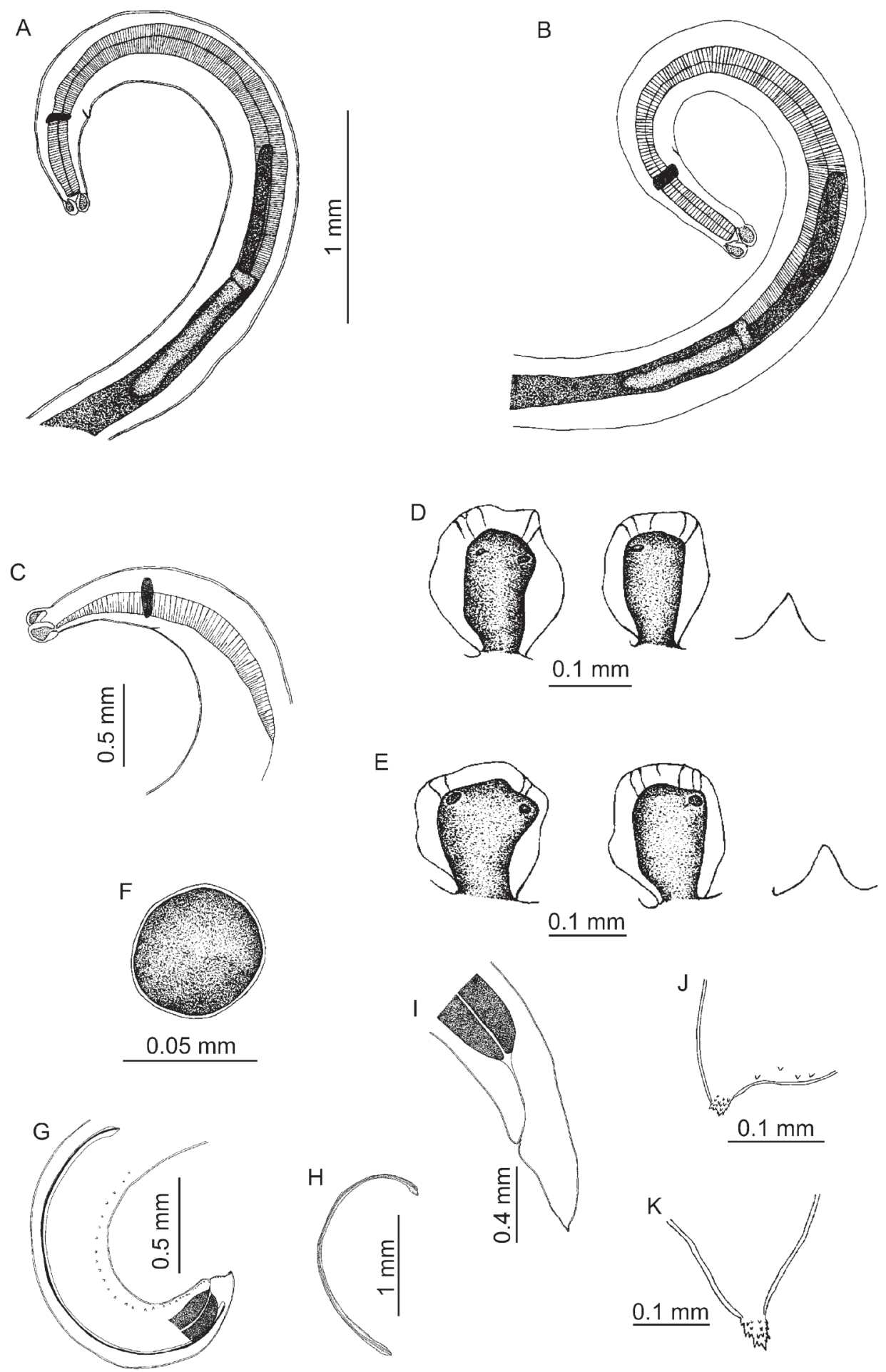

Fig. 2. Hysterothylacium aduncum gadi from Pollachius virens from Baltic Sea; $\mathrm{A}=$ head end of female, $\mathrm{B}=\mathrm{head}$ end of male, $\mathrm{C}=$ head end with lateral alae of male, $\mathrm{D}=$ dorsal lip, ventrolateral lip and interlabium of female, $\mathrm{E}=$ dorsal lip, ventrolateral lip and interlabium of male, $\mathrm{F}=\mathrm{egg}, \mathrm{G}=$ posterior end of male, $\mathrm{H}=$ spicule, $\mathrm{I}=$ posterior end of female, $\mathrm{J}=$ caudal process of male, $\mathrm{K}=$ caudal process of female

H. aduncum aduncum. The alae were $0.051 \mathrm{~mm}$ wide whereas in $H$. aduncum aduncum it is $>54$. Moreover, the (in a young female) and 0.151 and $0.158 \mathrm{~mm}$ wide (in ratio (ventricular caecum length : alae width) differs adult nematodes). It is worthwhile emphasizing that the among specimens of these subspecies, i.e., $<15$ and $>15$ in nematode with wider alae had the more bent anterior part H. aduncum gadi and H. aduncum aduncum, respectively of body. The ratio (oesophagus length : alae width) differ- (Petter and Cabaret 1995). Our specimens fit those measentiates the subspecies: in H. aduncum gadi it is $<54$ urements for $H$. aduncum gadi but had only 4 pairs of 
post-anal papillae rather than the 5 pairs reported by Petter and Cabaret (1995). We suspect that specimens of H. aduncum may have previously been misidentified as $H$. gadi. For example, the figures of Berland $(1961,1991)$ labelled as $H$. aduncum may represent $H$. aduncum gadi, which is strongly suggested by the characteristic bending caused by large alae. Unfortunately latter author failed to estimate the ratio of oesophagus and ventricular caecum length to alae width. Specimens of $H$. aduncum in our collection from cod and flounder in the Gulf of Gdańsk lack such alae. In view of the above, the records of Hysterothylacium spp. from the North Atlantic need re-confirmation.

\section{ACKNOWLEDGEMENTS}

This study was supported by the Ministry of Science and Higher Education, Grant No. 0420/PO4/2005/28.

\section{REFERENCES}

Balbuena J.A., Karlsbakk E., Saksvik M., Kvenseth A.M., Nylund A. 1998. New data on the early development of Hysterothylacium aduncum (Nematoda, Anisakidae). Journal of Parasitology 84: 615-617.

Berland B. 1961. Nematodes from some Norwegian marine fishes. Sarsia 2: 1-50.

Berland B. 1991. Hysterothylacium aduncum (Nematoda) in fish. ICES Identification leaflets for diseases and parasites of fish and shellfish, Leaflet No. 44.

Chibani M., Rokicki J. 2004. Seasonal occurrence of parasites of flounder Platichthys flesus (L.) from the Gulf of Gdańsk. Oceanological and Hydrobiological Studies 33: 17-30.

Froese R., Pauly D. (eds.) 2008. FishBase. World Wide Web electronic publication. www.fishbase.org. version (09/2008).

Hartwich G. 1975. Schlauchwürmer, Nemathelminthes Rundoder Fadenwürmer, Nematoda. Parasitische Rundwürmer von Wirbeltieren. 1. Rhabditida und Ascaridida. Die Tierwelt Deutschlands und der angrenzenden Meeresteile nach ihrer Merkmalen und nach ihrer Lebensweise, K. Senglaub, H.J. Hannemann, H. Schumann (eds.), vol. 62. VEB Gustav Fischer Verlag, Jena.

Karasev A.B., Mitenev V.K., Shulman B.S. 1996. Ecological peculiarities of the parasite fauna of cod and pollock in the vicinity of the Kislaya inlet tidal power plant, western Murman (the Barents Sea). Sarsia 80: 307-312.

Køie M. 1999. Metazoan parasites of flounder Platichthys flesus (L.) along a transect from the southwestern to the northeastern Baltic Sea. ICES Journal of Marine Sciences 56: 157-163.

Lom J. 2002. A catalogue of described genera and species of microsporidians parasitic in fish. Systematic Parasitology 53: 81-99.
Lomniewski K., Mańkowski W., Zaleski J. 1975. Morze Bałtyckie. [Baltic Sea.] PWN, Warszawa. [In Polish.]

Morozińska-Gogol J. 2006. A checklist of parasites recorded on sticklebacks (Actinopterygii: Gasterosteidae) from Poland. Parasitology International 55: 69-73.

Petter A.J., Cabaret J. 1995. Ascaridoid nematodes of teleostean fishes from the eastern north Atlantic and seas of the north of Europe. Parasite 2: 217-230.

Punt A. 1941. Recherches sur quelques nématodes parasites de poissons de la Mer du Nord. Mémoires du Musée Royal d'Histoire Naturelle de Belgique 98: 1-100.

Rhode K. 2002. Ecology and biogeography of marine parasites. Advances in Marine Biology 43: 1-86.

Rokicki J. 1975. Helminth fauna of fishes of the Gdańsk Bay (Baltic Sea). Acta Parasitologica Polonica 23: 37-84.

Rokicki J. 1995. Changes in the parasite fauna of cod Gadus morhua L. in the Gdańsk Bay. Scientific papers presented at the Polish-Swedish Symposium on Baltic cod, Gdynia, Poland, March 21-22, 1995. Meddelande Från Havsfiskelaboratoriet 327: 131-139.

Rokicki J., Strömberg J.O. 1991. Infestation dynamics of external parasites of saithe (Pollachius virens) from the North and Norwegian Seas. Wiadomości Parazytologiczne 37: 155-162.

Rokicki J., Valter E.D., Myjak P. 1993. Contracaecum osculatum (Nematoda, Anisakidae) in cod, Gadus morhua L. from the Polish coast of the Baltic. Acta Parasitologica 38: 33-35.

Rolbiecki L. 2003. Diversity of the parasite fauna of cyprinid (Cyprinidae) and percid (Percidae) fishes in the Vistula Lagoon, Poland. Wiadomości Parazytologiczne 49: 125-164.

Rolbiecki L., Rokicki J. 2000. The occurrence of the nematodes Anisakis simplex pathogenic to man in pike-perch from the Vistula Lagoon, Poland. Wiadomości Parazytologiczne 46: 397-402.

Strømnes E., Andersen K. 1998. Distribution of whaleworm (Anisakis simplex, Nematoda, Ascaridoidea) L3 larvae in three species of marine fish; saithe (Pollachius virens (L.)), cod (Gadus morhua L.) and redfish (Sebastes marinus (L.)) from Norwegian waters. Parasitology Research 84: 281-285.

Zander C.D., Reimer L.W. 2002. Parasitism at the ecosystem level in the Baltic Sea. Parasitology 124: S119-S135.

Received: 2 June 2008

Accepted: 21 October 2008

Published electronically: 15 December 2008 